\title{
Immunopathology of Japanese macaque encephalomyelitis is similar to multiple
}

\section{sclerosis}

Tiffany C. Blair ${ }^{1}$, Minsha Manoharan ${ }^{1}$, Stephanie D. Rawlings-Rhea ${ }^{1}$, lan Tagge ${ }^{2}$, Steven G. Kohama $^{3}$, Julie Hollister-Smith ${ }^{3}$, Betsy Ferguson ${ }^{3}$, Randall L. Woltjer ${ }^{4}$, Meredith C. Frederick ${ }^{5}$, James Pollaro², William D. Rooney ${ }^{2}$, Larry S. Sherman ${ }^{3}$, Dennis N. Bourdette ${ }^{5}$ and Scott W. Wong $^{1,6}$

${ }^{1}$ Vaccine and Gene Therapy Institute, Oregon Health \& Science University (OHSU), 505 NW $185^{\text {th }}$ Avenue, Beaverton, OR 97006 (email addresses: tiffany.blair@agonox.com, manohara@ohsu.edu,srawlingsd@gmail.com,wongs@ohsu.edu)

${ }^{2}$ Advanced Imaging Research Center, OHSU, 3181 SW Sam Jackson Park Road, Portland, OR 97239 (email addresses: taggei@ohsu.edu, jim.pollaro@gmail.com,rooneyw@ohsu.edu) ${ }^{3}$ Division of Neuroscience, Oregon National Primate Research Center (ONPRC), 505 NW $185^{\text {th }}$ Avenue, Beaverton, OR 97006 (email addresses: kohamas@ohsu.edu, Hollistersmith@comcast.net, fergusob@ohsu.edu, shermanl@ohsu.edu) ${ }^{4}$ Department of Pathology, OHSU, 3181 SW Sam Jackson Park Road, Portland, OR 97239 (email address: woltjerr@ohsu.edu)

${ }^{5}$ Department of Neurology, OHSU, 3181 SW Sam Jackson Park Road, Portland, OR 97239 (email address: frederim@ohsu.edu, bourdette@ohsu.edu)

${ }^{6}$ Division of Pathobiology and Immunology, ONPRC, 505 NW $185^{\text {th }}$ Avenue, Beaverton, OR 97006

To whom correspondence should be addressed:

Scott W. Wong, Ph.D.

Vaccine and Gene Therapy Institute

505 N.W. $185^{\text {th }}$ Avenue

Beaverton, OR 97006

Email:wongs@ohsu.edu 


\section{ABSTRACT}

Japanese macaque encephalomyelitis (JME) is an inflammatory demyelinating disease that occurs spontaneously in a colony of Japanese macaques (JM) at the Oregon National Primate Research Center. Animals with JME display clinical signs resembling multiple sclerosis (MS), and magnetic resonance imaging reveals multiple $T_{2}$-weighted hyperintensities and gadoliniumenhancing lesions in the central nervous system (CNS). Here we undertook studies to determine if JME possesses features of an immune-mediated disease in the CNS. Comparable to MS, the CNS of animals with JME contain active lesions positive for IL-17, CD4+ T cells with Th1 and Th17 phenotypes, CD8+ T cells, and positive CSF findings.

\section{KEYWORDS:}

Magnetic resonance imaging (MRI), inflammatory, demyelination, interleukin 17 (IL-17), Th1, Th17, and intrathecal $\lg G$

\subsection{Introduction}

Multiple sclerosis (MS) is widely believed to be an immune-mediated disease that leads to multifocal destruction of the myelin and to a lesser extent axonal degeneration. It is proposed that MS pathogenesis is driven by auto-reactive $T$ cells that aberrantly gain access to the central nervous system (CNS). Upon entry to the CNS, these T cells become reactivated when they recognize components of myelin, setting in motion a cascade of inflammatory events that ultimately lead to demyelination and axonal injury (Goverman, 2009). The mechanisms that trigger these T cells to become pathogenic are poorly understood, but genetic and environmental triggers are thought to play an important role (International Multiple Sclerosis Genetics et al., 2011). T cells expressing the cytokines IL-17 or IFN- $\gamma$ appear to be key players in disease development, as studies have shown that these populations are present in MS lesions (Kebir et al., 2009, Tzartos et al., 2008, Kebir et al., 2007). This highlights a central role 
for helper T cells (Th) in MS progression, and emphasizes the need to understand the function of these T cell subsets in order to further unravel the etiology of the disease (Waisman et al., 2015). Active MS lesions also contain CD8+ T cells, macrophages filled with myelin debris and reactive astrocytes (Popescu and Lucchinetti, 2012). Beyond the CNS, groups have reported an increased prevalence of auto-reactive myelin-specific T cells in the peripheral blood of MS patients (Kerlero de Rosbo et al., 1993, Hedegaard et al., 2008). However, conflicting results have been published showing that both healthy controls $(\mathrm{HC})$ and MS patients have similar frequencies of these T cells in the periphery (Hellings et al., 2001, Hellings et al., 2002). These data hint at the role of defective regulation in controlling these potentially pathogenic $T$ cells in MS patients as compared to HC.

B cells and plasma cells also play a significant role in MS immunopathogenesis, as their products are frequently detected in MS lesions and cerebrospinal fluid (CSF) (Berer et al., 2011, Probstel et al., 2015, Serafini et al., 2004). Importantly, the detection of intrathecally synthesized oligoclonal IgG bands (OCBs) in the CSF is a commonly used paraclinical measure to diagnose MS when utilized in conjunction with MRI and clinical history (Petzold, 2013, Bonnan, 2015). Further substantiating the role of B cells in MS are clinical trials with the anti-CD20 monoclonal antibodies, rituximab and ocrelizumab, a treatment that resulted in reduced inflammatory brain lesions as detected by MRI and decreased clinical relapses in subjects with relapsing MS (Hauser et al., 2008).

Animal models that mimic the immune-mediated aspects of MS are valuable in elucidating mechanisms associated with disease pathogenesis. The most widely utilized animal model to study MS is experimental autoimmune encephalomyelitis (EAE). EAE can be induced in a variety of species, including mice, rats and nonhuman primates (NHP). EAE induction involves immunizing animals with myelin proteins or peptides in Freund's complete adjuvant and results in T cell responses to myelin, focal inflammatory lesions within the CNS and ultimately leads to paralysis. EAE recapitulates the T cell-mediated aspects of MS, as studies find Th1 and Th17 
cells are necessary for the induction of EAE (Jager et al., 2009). However, while EAE studies have yielded useful insight into several facets of MS pathogenesis, this model has well recognized limitations. First, immunizing animals with myelin proteins or peptides artificially induces the disease EAE, while MS occurs as a spontaneous disease. Second, EAE is studied in inbred mouse strains and this is in large contrast to MS, which occurs, in a heterogeneous population with highly variable genetic diversity. Third, the relatively small size of mice constrains the imaging that can be performed using MRI, whereas an array of sophisticated MRI techniques are available to study MS. An animal model that overcomes these limitations would be of considerable use in advancing our understanding of MS.

In 2011, we described a spontaneous inflammatory CNS demyelinating disease, called Japanese macaque encephalomyelitis (JME), that occurs in $1 \%$ to $3 \%$ of the animals in our colony of Japanese macaques (JM, Macaca fuscata) at the Oregon National Primate Research Center (ONPRC) (Axthelm et al., 2011). We proposed that JME was a spontaneous NHP model for MS based on the appearance of brain lesions as detectable with MRI and the presence of multifocal demyelinating lesions as observed using histology. Here, we present evidence that JME shares many immunopathological similarities with MS. Specifically, we demonstrate that JME lesions possess similar immunohistopathological features as MS lesions, including active demyelination and significant T- and B-cell germinal areas surrounding perivascular and periventricular spaces. Importantly, immunofluorescence analysis revealed that within demyelinating lesions, both astrocytes and oligodendrocytes stain positively for interleukin 17 (IL-17). Moreover, multicolor flow cytometry analysis of infiltrating T cells revealed both $\mathrm{CD}^{+}$and $\mathrm{CD}^{+} \mathrm{T}$ cells that expressed IL-17 or IFN- $\gamma$, and in some instances both cytokines, similar to what has been shown in MS. Finally, we show that animals with JME have positive CSF findings that include an elevated IgG index and 2 or more oligoclonal bands, a common finding in MS (Polman et al., 2011). Collectively, these data support JME as a unique 
NHP model for a MS-like disease, which can be utilized to offer new insights into the pathogenesis of MS.

\subsection{Materials and Methods}

\subsection{Animals and animal procedures.}

All animal protocols and procedures were reviewed and approved by the ONPRC Institutional Animal Care and Use Committee. The ONPRC is an Association for Assessment and Accreditation of Laboratory Animal Care (AAALAC) International accredited research facility and conforms to National Institutes of Health guidelines on the ethical use of animals in research. JM exhibiting neurological dysfunction and symptoms associated with JME were brought in for physical examination and provided supportive care, and then scanned by MRI on a 3T Siemens TIM Trio MR instrument as previously described (Axthelm et al., 2011). Animals with progressive disease were humanely euthanized via exsanguination, with blood and CSF collection. The blood was immediately processed for plasma collection and peripheral blood mononuclear cell (PBMC) isolation. The CSF and serum were archived at $-80^{\circ} \mathrm{C}$, while PBMCs were cryopreserved. Animals were subsequently perfused with sterile PBS through carotid cannulation, the brain was removed and immersed fixed in $4 \%$ buffered paraformaldehyde solution. For some necropsies, lesion areas that were detected by MRI were collected from affected areas after the PBS perfusion step in order to obtain fresh brain tissue for lymphocyte analysis. A portion of each lesion was placed in RPMI media supplemented with $10 \%$ fetal bovine serum and processed as described to isolate CNS-infiltrating mononuclear cells (CNSMNCs) (Jager et al., 2009). In these cases the remainder of the brain was also immersed fixed in $4 \%$ neutral buffered paraformaldehyde solution for histopathological analysis. For comparisons to JME cases, blood and cisternal cerebrospinal fluid (CSF) samples were also collected from healthy controls $(\mathrm{HC})$ after sedation with Telazol during routine physical 
examinations, and then processed as above. Each $\mathrm{HC}$ was subsequently given Carprofen (4 $\mathrm{mg} / \mathrm{kg}$ ) subcutaneously to minimize discomfort.

\subsection{Histopathological examination.}

Fixed tissue was processed for paraffin embedding and subsequent histology. Fixed sections $(0.5 \mathrm{mM})$ from the CNS were prepared and stained with Luxol fast blue (LFB) and hematoxylin and eosin (H\&E) to visualize demyelinating regions and infiltrating inflammatory

cells. Sections containing lesions were treated essentially as described previously (Axthelm et al., 2011). For antigen detection analysis, the sections were deparaffinized, blocked with $10 \%$ goat serum and $5 \%$ bovine serum albumin, and endogenous peroxidase was quenched by standard techniques. Slides were treated with primary antibodies overnight at $4^{\circ} \mathrm{C}$ and then processed for color detection or immunofluorescence. Commercially available primary antibodies were used to detect the following cellular antigens and cell types: myelin basic protein (MBP, mouse anti-MBP, clone SMI 99; Covance, Princeton, NJ, 1:500), glial fibrillary acidic protein (GFAP, rabbit polyclonal anti-GFAP, RPCA-GFAP, EnCor Biotechnology, Gainsville, FL, 1:500), oligodendrocytes (rabbit anti-olig-2, AB9610, Millipore, Billerica, MA, 1:200), activated microglia (rabbit anti-IBA-1, 019-19741, Wako, Richmond, VA, 1:300), macrophages (mouse anti-human CD163, clone EDHu-1, AbD Serotec, Hercules, CA, 1:100), T cells (rabbit anti-human CD3, Dako, Carpinteria, CA, 1:200), B cells (mouse anti-CD20, clone L26, Dako, 1:200), activated complement C3d (rabbit polyclonal anti-3Cd, AB15981, Abcam, Cambridge, MA, 1:400) and IL-17 (mouse anti-IL17 F, clone 4H1629.1 Rockland, MD, 1:100).

For immunohistochemistry, detection of biotinylated secondary antibodies was performed with peroxidase $\mathrm{ABC}$ (Elite kit, Vector Laboratories, San Carlos, $\mathrm{CA}$ ) and visualization with $\mathrm{DAB}$ (Dako) for CD163 and activated complement 3Cd, and Vector SG for MBP (Vector Laboratories). For immunofluorescence detection, secondary biotinylated goat anti-mouse (Vector Laboratories) or goat anti-rabbit IgG $(\mathrm{H}+\mathrm{L})$ (Vector Laboratories) were used, followed by 
Elite ABC kit and further stained with streptavidin Alexa 488 (Molecular Probes, Eugene, OR) and streptavidin Alexa 594 (Molecular Probes), respectively, to visualize the antigens of interest. The sections were counterstained with 4,6'-diamino-2-phenylindole dihydrochloride (DAPI) (1:5000) and covered with Prolong gold anti-fade medium (Invitrogen, Carlsbad, CA) or Omnimount (National Diagnostics, Atlanta, Georgia). Sections were examined using a Zeiss Axio Imager M1 microscope (Carl Zeiss, Thornwood, NY) using Plan NeoFluar objective lenses $(2.5 \times / 0.5 \mathrm{NA}$ and $40 \times / 0.75 \mathrm{NA})$. Optical images were obtained with standard conditions of illumination and exposure on a Zeiss Axiocam camera (Carl Zeiss). Sections were routinely stained with isotype control monoclonal antibodies and the appropriate secondary antibodies, or secondary antibodies alone as negative controls. Normal JM CNS tissue was also stained to ensure specificity of the primary antibodies. An experienced neuropathologist examined the stained sections.

\subsection{CNS-MNC stimulation and flow cytometry analysis.}

Freshly purified CNS-MNCs were promptly stimulated with a cocktail of phorbol-12myristate-13 acetate (PMA) and lonomycin that included BrefeldinA (Leukocyte Activation Cocktail with BD GolgiPlug, BD Biosciences, San Jose, CA) for 6 hrs (Slywester, 2014). After stimulation CNS-MNCs were stained with CD4 (RPA-T4, eBioscience, San Diego, CA), CD8 $\beta$ (2ST8.5H7, Beckman Coulter, Brea, CA) and in some instances CD3 (SP34-2, BD Biosciences). Cells were subsequently fixed and permeabilized using fixation buffer and permeabilization buffer (Biolegend, San Diego, CA). Intracellular cytokine staining was performed using IL-17A (eBio64CAP17, eBioscience) and IFN- $\gamma$ (B27, BD Biosciences). All flow cytometry data were acquired on LSR II (BD Biosciences) and analyzed using FlowJo (Tree Star, Ashland, OR). 


\subsection{Intrathecal IgG analysis}

Quantification of IgG and albumin in paired CSF and plasma samples were performed at least twice in duplicate using a human IgG enzyme-linked immunosorbent assay (ELISA) alkaline phosphatase (ALP) kit (Mabtech, Cincinnati, OH) and a QuantiChrom BCG Albumin Assay Kit (BioAssay Systems, Hayward, CA), respectively. The CSF IgG index was calculated for all animals using the following formula (CSF IgG/CSF albumin)/(serum IgG/serum albumin) (Link and Tibbling, 1977). We defined a high CSF IgG index value as $\geq 1.0$, which was derived by adding two standard deviations (SD) to the HC mean. For OCBs analysis, paired unconcentrated CSF and diluted plasma samples were resolved by isoelectric focusing (IEF) and proteins were transferred and immunoblotted to identify lgG bands (Fortini et al., 2003). Three separate scientists evaluated the blots in a blinded fashion.

\subsection{Statistical analysis}

CSF data from JME and HC were analyzed for statistical analysis using GraphPad Prizm (GraphPad Software, La Jolla, CA), and significant differences in the means were determined by an unpaired $t$ test, with $p$ values of $\leq 0.05$ considered significant.

\subsection{Results}

\subsection{JME lesions possess histopathological features resembling MS.}

We previously reported that JME lesions contain significant T cell and macrophage infiltrates (Axthelm et al., 2011). To determine if these lesions displayed immunological signatures correlating with an immune-mediated disease, we evaluated a cohort of 11 Japanese macaques (JM) that presented with clinical signs of JME (Table 1). MRI scans were performed on all 11 animals and 2 cases are shown in Figure 1. A MRI of the brain and upper cord was performed on JM 220191 day after presentation with acute signs of JME. The $T_{2}$-weighted axial image in Figure $1 \mathrm{~A}$ showed both diffuse and hyperintense areas in the cerebellum. The post-gadolinium 
$\mathrm{T}_{1}$-weighted image revealed a single area of focal contrast enhancement in the white matter (WM) of the cerebellum when compared to the pre-gadolinium image (Fig. 1B). JM 30760 underwent an MRI 1 day after presentation of acute JME signs and the $\mathrm{T}_{2}$-weighted image in Figure $1 \mathrm{C}$ showed a hyperintense area in the internal capsule. Post-gadolinium $\mathrm{T}_{1}$-weighted image revealed a single area of focal contrast enhancement corresponding to the same area identified by the $T_{2}$-weighted image (Fig. 1D). Similar MRI abnormalities were observed in the other 9 cases of JME, with the cerebellum being the most common area of the brain affected (8/11 cases), followed by the cervical spinal cord (5/11 cases).

To characterize the neuropathology associated with JME, CNS tissues were collected from all of the animals and regions exhibiting demyelination were identified by histopathological examination using luxol fast blue (LFB) and hematoxylin-eosin (H\&E) stain. Shown in Figure 2A, B and C are low magnification images of the cerebellar lesion isolated from JM 22019, and internal capsule lesions from JMs 30760 and 30773, respectively. Each lesion reveals areas of myelin loss as noted by minimal to no LFB positive staining. A large pronounced perivascular lymphocytic cuff is seen adjacent to the demyelinated lesion isolated from JM 22019 (Fig. 2A), and the internal capsule lesion of JM 30760 revealed a vascularized area with focal concentrations of lymphocytes forming perivascular cuffs (Fig. 2B). Similar findings were observed in the internal capsule lesion of JM 30773 which affected the optic tract/lateral geniculate nucleus and revealed prominent immune cell aggregates in the periventricular space (Fig. 2C). These findings are consistent with our earlier characterization of JME lesions.

Each demyelinating lesion was subsequently analyzed by immunostaining to visualize macrophages containing myelin proteins and is the same method used to assess MS plaques for active demyelination (Frischer et al., 2015). Evidence of CD163+ macrophage/activated microglia immunoreactive for myelin basic protein (MBP) was detected in the lesions isolated from 9 JME animals, whereas 2 animals (JMs 27624 and 31509) possessed numerous CD163+ cells that were not immunoreactive for MBP. Representative immunostains from the cerebellar 
lesion isolated from JM 22019 and the internal capsule lesion of JM 30760 are shown (Fig. 2D and E). The internal capsule lesion from JM 30760 had notably fewer and sparsely located CD163+ macrophage/activated microglia immunoreactive for MBP. To identify the inflammatory cells in the aggregates on the periventricular surface of JM 30773 we immunostained the section with CD68, CD3 and CD20 and found a significant cluster of CD20+ B cells (Fig. 2F) with very few $\mathrm{CD} 3+\mathrm{T}$ cells within the aggregate and parenchyma (data not shown). Prominent B cell clusters were observed in multiple JME animals. Sections exhibiting CD163+ macrophage/activated microglia immunoreactive for MBP macrophages were also found to stain positively for activated complement $3 \mathrm{Cd}$ along axons and neurons (Fig. 2G and H). Interestingly, we found numerous microglial nodules in the normal appearing white matter surrounding the hippocampus near the periventricular lesion of JM 30773 (Fig. 2I). These additional histopathological findings are consistent with pathological findings observed within MS lesions (Barnett et al., 2009, Breij et al., 2008, Singh et al., 2013).

\subsection{JME lesions are positive for the pro-inflammatory cytokine IL-17}

The CNS lesions from the $11 \mathrm{JME}$ animals were subsequently immunostained for the presence of IL-17, a pro-inflammatory cytokine expressed in active MS lesions (Tzartos et al., 2008). Nine of the 11 lesions revealed prominent IL-17 positive staining. We used double immunofluorescence to identify the cell types positive for IL-17 and found that CD3+ T cells, olig2+ oligodendrocytes, and GFAP + activated astrocytes were positive for IL-17, respectively (Fig. 3C, F, I). IL-17 positive staining was not uniform amongst the 9 lesions, as we observed dual staining for IL-17 in CD3+ T cell in 8 lesions, olig2+//L-17+ staining in 8 lesions, and GFAP+/IL-17+ staining in 3 lesions. Only lesions from 3 JME animals (JMs 26174, 30760 and 30773) were positive for IL-17 in these 3 cell types and no IL-17+ staining was observed in CD163+ cells from any of the other lesions analyzed (data not shown). We did not detect IL-17+ staining in 1 animal's lesion, JM 30493. 


\subsection{JME lesions harbor infiltrating IL-17 and IFN- $\gamma$-producing T cells}

To investigate the phenotype of infiltrating T cells, we isolated mononuclear cells (MNCs) from gadolinium-enhancing lesions of $5 \mathrm{JME}$ animals and used flow cytometry to characterize these populations. Our analysis showed $50 \%$ to $80 \%$ of infiltrating lymphocytes were either $\mathrm{CD}^{+}$or $\mathrm{CD} 8^{+} \mathrm{T}$ cells (Fig $4 \mathrm{~A}$ ). The $\mathrm{CD} 4^{+}$to $\mathrm{CD} 8^{+} \mathrm{T}$ cell ratio varied amongst the 5 animals. Lesions from 3 animals (JMs 22019, 27624 and 31522) had almost twice as many CD4 ${ }^{+} \mathrm{T}$ cells as CD8 ${ }^{+} \mathrm{T}$ cells, while lesions from 2 animals (JMs 31509 and 31852) had almost 3 times as many $\mathrm{CD} 8^{+} \mathrm{T}$ cells as $\mathrm{CD} 4^{+} \mathrm{T}$ cells.

Next we wanted to determine if lesions from JME animals harbored infiltrating IL-17 or IFN$\gamma$ producing T cells. These cells are hypothesized to play an important role in MS development and are highly enriched in CNS lesions from MS patients (Tzartos et al., 2008, Montes et al., 2009). Purified MNCs collected from the lesions of JMs 27624, 31522 and 31852 were stimulated with PMA and ionomycin, followed by intracellular cytokine staining for IL-17 and IFN- $\gamma$. Each animal exhibited different patterns of cytokine expression within their T cell compartments (Fig. 4B). The lesion from JM 27624 contained a large percentage of cytokineproducing cells, which were IFN- $\gamma^{+}\left(\mathrm{CD} 4^{+}, 27.8 \%\right.$; $\left.\mathrm{CD}^{+}, 66.7 \%\right), \mathrm{IL}^{-17^{+}}\left(\mathrm{CD} 4^{+}, 13.7 \%\right.$; $\mathrm{CD} 8^{+}$, $3.45 \%)$ or IFN- $\gamma^{+} / \mathrm{IL}-17^{+}\left(\mathrm{CD}^{+}, 14.2 \%\right.$; $\left.\mathrm{CD}^{+}, 18.2 \%\right)$ expressing T cells. JM 31852 had fewer cytokine-producing $\mathrm{T}$ cells overall and these cells primarily expressed IFN- $\gamma\left(\mathrm{CD}^{+}, 19.9 \%\right.$; CD8 $\left.{ }^{+}, 37.5 \%\right)$. A small percentage of the infiltrates were Th17 cells $(8.96 \%)$ and hardly any double producers were present $\left(C D 4^{+}, 0.58 \%\right.$; $\left.C D 8^{+}, 0.68 \%\right)$. T cell infiltrates from JM 31522 displayed a similar expression profile to JM 27624, albeit with a lower percentage of cytokineproducing cells $\left[\mathrm{IFN}-\gamma^{+}\left(\mathrm{CD} 4^{+}, 12.1 \%\right.\right.$; $\left.\mathrm{CD}^{+}, 44.3 \%\right), \mathrm{IL}^{-17^{+}}\left(\mathrm{CD} 4^{+}, 12.6 \%\right.$; $\left.\left.\mathrm{CD} 8^{+}, 5.48 \%\right)\right]$. Unlike JM 27624, the lesion from JM 31522 had limited accumulations of IFN- $\gamma^{+} / \mathrm{LL}-17^{+}$doublepositive cells in either T cell compartment $\left(\mathrm{CD}^{+}, 2.24 \%\right.$; and $\left.\mathrm{CD} 8^{+}, 3.41 \%\right)$. These data indicate 
active lesions in the CNS of JME animals harbor infiltrating T cells that exhibit Th1 and Th17 phenotypes.

\subsection{B cell processes occur in JME}

The presence of CD20+ cell clusters in the CNS of JME suggests that B cells may be contributing to disease pathogenesis. To further evaluate the role of B cell processes in JME, we analyzed CSF and blood samples from 9 JME animals and 11 age- and gender-matched healthy controls $(\mathrm{HC})$ and performed a comparative IgG analysis. First, we determined the concentration of IgG and albumin in both the CSF and plasma for each animal. Notably, we found that the mean CSF IgG concentration for JME animals was 13.3 times higher than that of $\mathrm{HC}$ animals $[4.39 \mathrm{mg} / \mathrm{dL} \pm 1.45$, standard error of the mean (SEM) for JME versus $0.31 \mathrm{mg} / \mathrm{dL} \pm$ 0.05 SEM)] (Fig. 5A). The differences observed between the CSF IgG concentrations were statistically significant $(p<0.006$, unpaired t test), whereas the plasma IgG concentrations were not. Additionally, we found that the CSF albumin concentrations were statistically higher $(p<0.004$, unpaired $t$ test) in the JME animals $(57.1 \pm 8.63$ SEM) than the HC $(30.27 \pm 2.47$ SEM), which could be explained by a leaky blood brain barrier (BBB) in JME animals, as these animals had gadolinium-enhanced lesions (data not shown).

Although elevated CSF IgG concentrations are an indicator of abnormal B cell processes occurring in the CNS, calculating the CSF IgG index is considered more reliable as it corrects for IgG appearing in CSF because of increased BBB permeability (Freedman et al., 2005, Polman et al., 2011, Tumani et al., 2011, Link and Tibbling, 1977). The CSF IgG index was calculated for each animal and we found that JME animals have an elevated mean CSF IgG index of $1.23 \pm 0.26$ SEM, compared to $\mathrm{HC}$ (mean CSF IgG index of $0.36 \pm 0.1$ SEM), which was statistically significant ( $p<0.003$, unpaired t test) (Fig. 5B).

Lastly, we evaluated the CSF from JME and HC animals for the presence of 2 or more OCBs, as this sensitive qualitative assay is an indicator of the intrathecal IgG synthesis. Paired 
unconcentrated CSF and diluted plasma from animals with JME and HC were run on IEF agarose gels and then transferred to a nitrocellulose membrane and immunostained for $\operatorname{lgG}$. We found 2 or more OCBs in the CSF of 7/9 JME animals, whereas the age- and gender-matched HCs showed no evidence of OCBs (Fig. 5C). By these 2 CSF analyses, all 9 JME animals had positive CSF findings (Table 2).

\subsection{Discussion}

Based upon our earlier publication, JME is most similar to 2 human diseases, MS and acute disseminated encephalomyelitis (ADEM). Given that JME can follow a relapsing course, clinically it is most similar to MS. Whereas the acuity of onset and relatively high mortality rate appears to resemble ADEM (Steiner, 2011). Here, we undertook an immunological based study within this colony of JMs to determine whether JME resembles MS, ADEM or a distinct demyelinating disease. First, we utilized immunopathological techniques that are commonly used in MS neuropathology to further characterize JME lesions. We found that a majority of the demyelinating lesions harbored macrophage/activated microglia cells that were immunoreactive for MBP. We considered these active lesions, as this is the accepted classification in MS. One caveat regarding this characterization is that we did not investigate whether macrophages/activated microglia were immunoreactive for any other myelin components such as myelin oligodendrocytes glycoprotein, myelin-associated glycoprotein, or cyclic nucleotide phosphodiesterase. Had we performed this analysis the 2 JME animals that did not exhibit active demyelination (CD163+/MBP+) might have been immunoreactive for these myelin components. Future cases will include these targets to define if JME lesions can be characterized as early active lesion or late active lesions (Frischer et al., 2015).

Second, utilizing double immunofluorescence techniques we detected IL-17 positive staining within JME lesions. This recapitulates data from EAE and MS where IL-17 has been shown to be an important cytokine in disease pathogenesis (Pierson et al., 2012, Baeten and Kuchroo, 
2013). Notably, IL-17 is not central to ADEM development or progression (Ishizu et al., 2006). Our data closely parallels findings reported for MS as we detected production of IL-17 in CD3+ T cells, and IL-17 positive staining in oligodendrocytes and astrocytes in the lesioned tissue (Tzartos et al., 2008). Importantly, the finding that isolated infiltrating MNCs from lesions in the CNS are comprised largely of CD4+ and CD8+ T cells further substantiated our discoveries. This observation correlates with published reports from MS lesions using immunohistochemistry, T cell receptor (TCR) repertoire usage defined by PCR amplification, and flow cytometry (Babbe et al., 2000, Montes et al., 2009, Axthelm et al., 2011, Tzartos et al., 2008). More importantly, the infiltrating CD4+ T cells possessed both Th1 and Th17 phenotypes, which are widely accepted to play a relevant role in MS immunopathogenesis (Lovett-Racke et al., 2011, Montes et al., 2009, Tzartos et al., 2008, Jadidi-Niaragh and Mirshafiey, 2011, Wingerchuk and Lucchinetti, 2007). We noted some variability in the composition of CNS infiltrating cells amongst animals and we suspect that this is most likely the manifestation of each animal presenting at varying disease stages prior to sample collection. Additional studies will be essential to determine if this diversity is consistent with animals and stages of disease.

Finally, our histopathological and CSF analyses demonstrate that B cells play a role in neuropathogenesis in JME animals, as these animals have significant B cell clusters in periventricular spaces. Importantly, we found that JME lesions were also positive for activated complement C3d deposition, which although not specifically indicative of MS, indicates that intrathecal antibodies may play a role in pathogenesis of JME (Barnett et al., 2009). Additionally, JME animals evaluated had positive CSF findings, paralleling data shown in MS (Serafini et al., 2004, Magliozzi et al., 2010). In the clinical setting positive CSF findings are frequently used to help diagnose MS and to help differentiate between MS and ADEM (Link and Huang, 2006, Polman et al., 2011, Steiner and Kennedy, 2015). 
Here we further define a spontaneous NHP model of inflammatory demyelination, JME that bears striking resemblance to MS. Animals presenting with JME possess MRI detectable lesions in the periventricular region, cerebellum, brain stem and spinal cord, which are regions commonly found to harbor lesions in MS patients (Trip and Miller, 2005). Additionally, these animals possess immunological signatures that are more akin to immunopathogenesis of MS than those of ADEM (Parrish and Yeh, 2012, Wingerchuk and Lucchinetti, 2007, Steiner and Kennedy, 2015). Importantly, animals that develop JME are from distinct matrilines of the original JM troop, suggesting that host genetic factors contribute to risk of disease. We also believe an infectious etiology may be associated with JME, as animals were PCR positive for Japanese macaque rhadinovirus (JMRV) infection, a simian gamma-herpesvirus we reported earlier to be present in JME lesions (Axthelm et al., 2011, Estep et al., 2013). Genetic susceptibility and an infectious etiology are two factors that are postulated to be associated with the induction of MS. Other environmental factor(s), such as vitamin D are also considered to be integral. In summary, this model has the potential to provide insight into a disease that has proven incredibly difficult to study, as the existing experimentally induced animal models do not recapitulate all aspects of MS (Procaccini et al., 2015). One of the major roadblocks in studying MS directly has been the inability to characterize CNS infiltrating immune cells directly ex vivo. This has severely limited our understanding of these potentially pathogenic cells and the extent of their involvement in disease pathogenesis. Future studies will be aimed at investigating the triggers that lead to disease development, as well as further characterization of the immunological processes associated with JME. Ultimately findings from these studies will lead to the discovery of mechanisms driving MS.

\section{CONCLUSIONS}

We found that JME cases encompass several key signatures that are associated with MS, including comparable MRI results, IL-17 production within CNS lesions, and positive CSF 
findings. In addition, analysis using flow cytometry showed that CNS-infiltrating T cells from JME cases exhibited Th1 and Th17 phenotypes that are thought to be associated with MS immunopathogenesis. We conclude that the JME animal model will provide researchers with access to types of studies that are not otherwise feasible in MS patients and have exciting implications for identifying and targeting pathways that can be used to treat MS.

\section{LIST OF ABBREVIATIONS}

ADEM, acute demyelinating encephalomyelitis; AAALAC, Association for Assessment and Accreditation of Laboratory Animal Care International; CNS, central nervous system; CSF, cerebrospinal fluid; dL, deciliter; ELISA, enzyme-linked immunosorbent assay; HC, healthy controls; H\&E, hematoxylin and eosin; IL-17, interleukin 17; IEF, isoelectric focusing; IgG, gamma-immunoglobulin; JM, Japanese macaque; JME, Japanese macaque encephalomyelitis; LFB, luxol fast blue; mg, milligram; MNC, mononuclear cells; MBP, myelin basic protein; MOG, myelin oligodendrocytes glycoprotein; MPRAGE, magnetization prepared rapid acquisition gradient echo; MRI, magnetic resonance imaging; MS, multiple sclerosis; OCBs, oligoclonal bands; ONPRC, Oregon National Primate Research Center; PBS, phosphate buffered saline; PLP, proteolipid protein; PMA, phorbol myristate acetate; SD, standard deviation; SEM, standard error of the mean; TCR, T cell receptor; Th1, T helper cell type 1; Th17, T helper 17 cell.

\section{COMPETING INTERESTS}

TCB, MM, SDR, IT, JP, SGK, JHS and BF have no competing interests. WDR received grants from Vertex Pharmaceuticals. MCF, LSS, DNB and SWW each received research support from the National Multiple Sclerosis Society (NMSS).

\section{Authors' contributions}


TCB participated in the design of the study, collected and processed the biological material, including blood and CSF, and infiltrating CNS MNC. She also performed the T cell analysis on infiltrating MNC, and participated in the writing of the manuscript. MM participated in the design of the study and performed immunohistopathological and immunofluorescence analysis on the CNS lesions and performed ELISA tests to quantify lgG, and assisted in the preparation of the manuscript. SDR participated in the design of the study, performed the ELISA tests to quantify $\lg G$ and albumin, performed the IEF and immunoblot assays to detect IgG OCBs, and assisted in the preparation of the manuscript. IT and JP performed the MR imaging on the Siemens TIM Trio 3T instrument, and IT analyzed the imaging data. SGK performed histological dissection of the CNS tissue for histopathological examination, assisted in the analysis of the MRI scans and participated in the preparation of the manuscript. JHS and BG provided JM parentage data to identify animals from affected matrilines. RLW and MCF performed the pathological analysis on JME cases and participated in the preparation of the manuscript. WDR developed the MR scanning protocol and analyzed the MRI scans. LSS provided immunohistopathological analysis, analyzed the OCB immunoblots and participated in the preparation of the manuscript. DNB participated in the study design and preparation of the manuscript. SWW participated in the study design, the analysis of the data, and prepared the manuscript. All authors read and approved the final manuscript.

\section{ACKNOWLEDGMENTS}

The authors thank the dedicated animal care staff at the ONPRC for the humane treatment of the animals exhibiting JME, and Ms. Kristin Fitzpatrick and Ms. Lori Boshears for proof reading. This research was supported by a United States Department of Defense grant (W81XWH-09-1-0276) (LSS, BF, SGK, WDR, and SWW), a National Institutes of Health grant

(P51OD011092-54) (BF, SGK, LSS and SWW), a Sylvia Lawry Fellowship from the National MS 
Society (MCF), and support from the Laura Fund for Multiple Sclerosis Research (DNB and SWW).

\section{REFERENCES}

AXTHELM, M. K., BOURDETTE, D. N., MARRACCI, G. H., SU, W., MULLANEY, E. T., MANOHARAN, M., KOHAMA, S. G., POLLARO, J., WITKOWSKI, E., WANG, P., ROONEY, W. D., SHERMAN, L. S. \& WONG, S. W. 2011. Japanese macaque encephalomyelitis: A spontaneous multiple sclerosis-like disease in a nonhuman primate. Annals of Neurology, 70, 362-373.

BABBE, H., ROERS, A., WAISMAN, A., LASSMANN, H., GOEBELS, N., HOHLFELD, R., FRIESE, M., SCHRODER, R., DECKERT, M., SCHMIDT, S., RAVID, R. \& RAJEWSKY, K. 2000. Clonal expansions of CD8(+) T cells dominate the T cell infiltrate in active multiple sclerosis lesions as shown by micromanipulation and single cell polymerase chain reaction. J Exp Med, 192, 393-404.

BAETEN, D. L. \& KUCHROO, V. K. 2013. How Cytokine networks fuel inflammation: Interleukin-17 and a tale of two autoimmune diseases. Nat Med, 19, 824-5.

BARNETT, M. H., PARRATT, J. D., CHO, E. S. \& PRINEAS, J. W. 2009. Immunoglobulins and complement in postmortem multiple sclerosis tissue. Ann Neurol, 65, 32-46.

BERER, K., WEKERLE, H. \& KRISHNAMOORTHY, G. 2011. B cells in spontaneous autoimmune diseases of the central nervous system. Mol Immunol, 48, 1332-7.

BONNAN, M. 2015. Intrathecal IgG synthesis: a resistant and valuable target for future multiple sclerosis treatments. Mult Scler Int, 2015, 296184.

BREIJ, E. C., BRINK, B. P., VEERHUIS, R., VAN DEN BERG, C., VLOET, R., YAN, R., DIJKSTRA, C. D., VAN DER VALK, P. \& BO, L. 2008. Homogeneity of active demyelinating lesions in established multiple sclerosis. Ann Neurol, 63, 16-25. 
ESTEP, R. D., HANSEN, S. G., ROGERS, K. S., AXTHELM, M. K. \& WONG, S. W. 2013. Genomic characterization of Japanese macaque rhadinovirus, a novel herpesvirus isolated from a nonhuman primate with a spontaneous inflammatory demyelinating disease. Journal of Virology, 87, 512-23.

FORTINI, A. S., SANDERS, E. L., WEINSHENKER, B. G. \& KATZMANN, J. A. 2003. Cerebrospinal fluid oligoclonal bands in the diagnosis of multiple sclerosis. Isoelectric focusing with IgG immunoblotting compared with high-resolution agarose gel electrophoresis and cerebrospinal fluid IgG index. Am J Clin Pathol, 120, 672-5.

FREEDMAN, M. S., THOMPSON, E. J., DEISENHAMMER, F., GIOVANNONI, G., GRIMSLEY, G., KEIR, G., OHMAN, S., RACKE, M. K., SHARIEF, M., SINDIC, C. J., SELLEBJERG, F. \& TOURTELLOTTE, W. W. 2005. Recommended standard of cerebrospinal fluid analysis in the diagnosis of multiple sclerosis: a consensus statement. Arch Neurol, 62, 865-70.

FRISCHER, J. M., WEIGAND, S. D., GUO, Y., KALE, N., PARISI, J. E., PIRKO, I., MANDREKAR, J., BRAMOW, S., METZ, I., BRUCK, W., LASSMANN, H. \& LUCCHINETTI, C. F. 2015. Clinical and pathological insights into the dynamic nature of the white matter multiple sclerosis plaque. Ann Neurol.

GOVERMAN, J. 2009. Autoimmune T cell responses in the central nervous system. Nat Rev Immunol, 9, 393-407.

HAUSER, S. L., WAUBANT, E., ARNOLD, D. L., VOLLMER, T., ANTEL, J., FOX, R. J., BAROR, A., PANZARA, M., SARKAR, N., AGARWAL, S., LANGER-GOULD, A., SMITH, C. H. \& GROUP, H. T. 2008. B-cell depletion with rituximab in relapsing-remitting multiple sclerosis. N Engl J Med, 358, 676-88.

HEDEGAARD, C. J., KRAKAUER, M., BENDTZEN, K., LUND, H., SELLEBJERG, F. \& NIELSEN, C. H. 2008. Thelper cell type 1 (Th1), Th2 and Th17 responses to myelin basic protein and disease activity in multiple sclerosis. Immunology, 125, 161-9. 
HELLINGS, N., BAREE, M., VERHOEVEN, C., D'HOOGHE M, B., MEDAER, R., BERNARD, C. C., RAUS, J. \& STINISSEN, P. 2001. T-cell reactivity to multiple myelin antigens in multiple sclerosis patients and healthy controls. J Neurosci Res, 63, 290-302.

HELLINGS, N., GELIN, G., MEDAER, R., BRUCKERS, L., PALMERS, Y., RAUS, J. \& STINISSEN, P. 2002. Longitudinal study of antimyelin T-cell reactivity in relapsingremitting multiple sclerosis: association with clinical and MRI activity. J Neuroimmunol, $126,143-60$.

INTERNATIONAL MULTIPLE SCLEROSIS GENETICS, C., WELLCOME TRUST CASE CONTROL, C., SAWCER, S., HELLENTHAL, G., PIRINEN, M., SPENCER, C. C., PATSOPOULOS, N. A., MOUTSIANAS, L., DILTHEY, A., SU, Z., FREEMAN, C., HUNT, S. E., EDKINS, S., GRAY, E., BOOTH, D. R., POTTER, S. C., GORIS, A., BAND, G., OTURAI, A. B., STRANGE, A., SAARELA, J., BELLENGUEZ, C., FONTAINE, B., GILLMAN, M., HEMMER, B., GWILLIAM, R., ZIPP, F., JAYAKUMAR, A., MARTIN, R., LESLIE, S., HAWKINS, S., GIANNOULATOU, E., D'ALFONSO, S., BLACKBURN, H., MARTINELLI BONESCHI, F., LIDDLE, J., HARBO, H. F., PEREZ, M. L., SPURKLAND, A., WALLER, M. J., MYCKO, M. P., RICKETTS, M., COMABELLA, M., HAMMOND, N., KOCKUM, I., MCCANN, O. T., BAN, M., WHITTAKER, P., KEMPPINEN, A., WESTON, P., HAWKINS, C., WIDAA, S., ZAJICEK, J., DRONOV, S., ROBERTSON, N., BUMPSTEAD, S. J., BARCELLOS, L. F., RAVINDRARAJAH, R., ABRAHAM, R., ALFREDSSON, L., ARDLIE, K., AUBIN, C., BAKER, A., BAKER, K., BARANZINI, S. E., BERGAMASCHI, L., BERGAMASCHI, R., BERNSTEIN, A., BERTHELE, A., BOGGILD, M., BRADFIELD, J. P., BRASSAT, D., BROADLEY, S. A., BUCK, D., BUTZKUEVEN, H., CAPRA, R., CARROLL, W. M., CAVALLA, P., CELIUS, E. G., CEPOK, S., CHIAVACCI, R., CLERGET-DARPOUX, F., CLYSTERS, K., COMI, G., COSSBURN, M., COURNU-REBEIX, I., COX, M. B., COZEN, W., CREE, B. A., CROSS, A. H., CUSI, D., DALY, M. J., DAVIS, E., DE BAKKER, P. I., DEBOUVERIE, M., D'HOOGHE M, B., 
DIXON, K., DOBOSI, R., DUBOIS, B., ELLINGHAUS, D., et al. 2011. Genetic risk and a primary role for cell-mediated immune mechanisms in multiple sclerosis. Nature, 476, 214-9.

ISHIZU, T., MINOHARA, M., ICHIYAMA, T., KIRA, R., TANAKA, M., OSOEGAWA, M., HARA, T., FURUKAWA, S. \& KIRA, J.-I. 2006. CSF cytokine and chemokine profiles in acute disseminated encephalomyelitis. Journal of Neuroimmunology, 175, 52-58.

JADIDI-NIARAGH, F. \& MIRSHAFIEY, A. 2011. Th17 cell, the new player of neuroinflammatory process in multiple sclerosis. Scand J Immunol, 74, 1-13.

JAGER, A., DARDALHON, V., SOBEL, R. A., BETTELLI, E. \& KUCHROO, V. K. 2009. Th1, Th17, and Th9 effector cells induce experimental autoimmune encephalomyelitis with different pathological phenotypes. J Immunol, 183, 7169-77.

KEBIR, H., IFERGAN, I., ALVAREZ, J. I., BERNARD, M., POIRIER, J., ARBOUR, N., DUQUETTE, P. \& PRAT, A. 2009. Preferential recruitment of interferon-gammaexpressing TH17 cells in multiple sclerosis. Ann Neurol, 66, 390-402.

KEBIR, H., KREYMBORG, K., IFERGAN, I., DODELET-DEVILLERS, A., CAYROL, R., BERNARD, M., GIULIANI, F., ARBOUR, N., BECHER, B. \& PRAT, A. 2007. Human TH17 lymphocytes promote blood-brain barrier disruption and central nervous system inflammation. Nat Med, 13, 1173-5.

KERLERO DE ROSBO, N., MILO, R., LEES, M. B., BURGER, D., BERNARD, C. C. \& BENNUN, A. 1993. Reactivity to myelin antigens in multiple sclerosis. Peripheral blood lymphocytes respond predominantly to myelin oligodendrocyte glycoprotein. J Clin Invest, 92, 2602-8.

LINK, H. \& HUANG, Y. M. 2006. Oligoclonal bands in multiple sclerosis cerebrospinal fluid: an update on methodology and clinical usefulness. J Neuroimmunol, 180, 17-28. 
LINK, H. \& TIBBLING, G. 1977. Principles of albumin and IgG analyses in neurological disorders. II. Relation of the concentration of the proteins in serum and cerebrospinal fluid. Scand J Clin Lab Invest, 37, 391-6.

LOVETT-RACKE, A. E., YANG, Y. \& RACKE, M. K. 2011. Th1 versus Th17: are T cell cytokines relevant in multiple sclerosis? Biochim Biophys Acta, 1812, 246-51.

MAGLIOZZI, R., HOWELL, O. W., REEVES, C., RONCAROLI, F., NICHOLAS, R., SERAFINI, B., ALOISI, F. \& REYNOLDS, R. 2010. A Gradient of neuronal loss and meningeal inflammation in multiple sclerosis. Ann Neurol, 68, 477-93.

MONTES, M., ZHANG, X., BERTHELOT, L., LAPLAUD, D. A., BROUARD, S., JIN, J., ROGAN, S., ARMAO, D., JEWELLS, V., SOULILLOU, J. P. \& MARKOVIC-PLESE, S. 2009. Oligoclonal myelin-reactive T-cell infiltrates derived from multiple sclerosis lesions are enriched in Th17 cells. Clin Immunol, 130, 133-44.

PARRISH, J. B. \& YEH, E. A. 2012. Acuted disseminated encephalomyelitis. Adv Exp Med Biol, 724, 1-14.

PETZOLD, A. 2013. Intrathecal oligoclonal IgG synthesis in multiple sclerosis. J Neuroimmunol, 262, 1-10.

PIERSON, E., SIMMONS, S. B., CASTELLI, L. \& GOVERMAN, J. M. 2012. Mechanisms regulating regional localization of inflammation during CNS autoimmunity. Immunological reviews, 248, 205-15.

POLMAN, C. H., REINGOLD, S. C., BANWELL, B., CLANET, M., COHEN, J. A., FILIPPI, M., FUJIHARA, K., HAVRDOVA, E., HUTCHINSON, M., KAPPOS, L., LUBLIN, F. D., MONTALBAN, X., O'CONNOR, P., SANDBERG-WOLLHEIM, M., THOMPSON, A. J., WAUBANT, E., WEINSHENKER, B. \& WOLINSKY, J. S. 2011. Diagnostic criteria for multiple sclerosis: 2010 revisions to the McDonald criteria. Ann Neurol, 69, 292-302.

POPESCU, B. F. \& LUCCHINETTI, C. F. 2012. Pathology of demyelinating diseases. Annu Rev Pathol, 7, 185-217. 
PROBSTEL, A. K., SANDERSON, N. S. \& DERFUSS, T. 2015. B Cells and Autoantibodies in Multiple Sclerosis. Int J Mol Sci, 16, 16576-92.

PROCACCINI, C., DE ROSA, V., PUCINO, V., FORMISANO, L. \& MATARESE, G. 2015. Animal models of Multiple Sclerosis. Eur J Pharmacol, 759, 182-91.

SERAFINI, B., ROSICARELLI, B., MAGLIOZZI, R., STIGLIANO, E. \& ALOISI, F. 2004. Detection of ectopic B-cell follicles with germinal centers in the meninges of patients with secondary progressive multiple sclerosis. Brain Pathol, 14, 164-74.

SINGH, S., METZ, I., AMOR, S., VAN DER VALK, P., STADELMANN, C. \& BRUCK, W. 2013. Microglial nodules in early multiple sclerosis white matter are associated with degenerating axons. Acta Neuropathol, 125, 595-608.

SLYWESTER, A. W., HANSEN, S.G., PICKER, L.J. 2014. Quantitation of T cell antigen-specific memory responses in rhesus macaques, using cytokine flow cytometry (CFC, also known as ICS and ICCS): from assay set-up to data acquisition. Bio-Protocol.org. April 20, 2014 ed.

STEINER, I. 2011. On human disease and animal models. Annals of Neurology, 70, 343-344.

STEINER, I. \& KENNEDY, P. G. 2015. Acute disseminated encephalomyelitis: current knowledge and open questions. J Neurovirol.

TRIP, S. A. \& MILLER, D. H. 2005. Imaging in multiple sclerosis. J Neurol Neurosurg Psychiatry, 76 Suppl 3, iii11-iii18.

TUMANI, H., DEISENHAMMER, F., GIOVANNONI, G., GOLD, R., HARTUNG, H. P., HEMMER, B., HOHLFELD, R., OTTO, M., STANGEL, M., WILDEMANN, B. \& ZETTL, U. K. 2011. Revised McDonald criteria: the persisting importance of cerebrospinal fluid analysis. Ann Neurol, 70, 520; author reply 521.

TZARTOS, J. S., FRIESE, M. A., CRANER, M. J., PALACE, J., NEWCOMBE, J., ESIRI, M. M. \& FUGGER, L. 2008. Interleukin-17 Production in Central Nervous System-Infiltrating T 
Cells and Glial Cells Is Associated with Active Disease in Multiple Sclerosis. The American Journal of Pathology, 172, 146-155.

WAISMAN, A., HAUPTMANN, J. \& REGEN, T. 2015. The role of IL-17 in CNS diseases. Acta Neuropathol, 129, 625-37.

WINGERCHUK, D. M. \& LUCCHINETTI, C. F. 2007. Comparative immunopathogenesis of acute disseminated encephalomyelitis, neuromyelitis optica, and multiple sclerosis. Curr Opin Neurol, 20, 343-50.

\section{FIGURE LEGENDS}

Figure 1. MRI from animals with JME. Axial 3T MRI from JM 22019 (A and B) and JM 30760 (C and D) 1 day after presentation with clinical signs of JME. A. Axial $\mathrm{T}_{2}$-weighted image of cerebellum from JM 22019 shows hyperintense signal identified by arrow. B. Axial $\mathrm{T}_{1}$-weighted MPRAGE image acquired 40 minutes post- $0.2 \mathrm{mmol} / \mathrm{kg}$ gadoteridol administration shows an enhancing lesion in cerebellum; more readily visualized in the inset which represents a difference image $T_{1}$-weighted (pre-gadoteridol) subtracted from $T_{1}$-weighted (post-gadoteridol). C. Axial $\mathrm{T}_{2}$-weighted image of JM 30760 shows hyperintense signal in the internal capsule region of the cerebral cortex (arrow). D. Axial post-gadoteridol $\mathrm{T}_{1}$-weighted image shows enhancing lesion in the internal capsule; expanded in the inset showing difference image as in panel $B$. The lesion enhances on a $T_{1}$ - weighted MPRAGE image acquired 6 minutes after the administration of gadoteridol. MPRAGE $=$ magnetization prepared rapid acquisition gradient echo.

Figure 2. Histopathology and immunostained images of gadolinium-enhancing CNS lesions acquired from JME animals. A. Low magnification (2.5x) image of luxol fast blue (LFB) and hematoxylin-eosin (H\&E) stain of cerebellar lesion from JM 22019 shows demyelinated region adjacent to perivascular cuff surrounding the blood vessel. Arrowhead 
points to the demyelinated region. B and C. Low magnification (2.5x) images of LFB/H\&E stain of internal capsule lesions from JM 30760 and JM 30773, respectively. Arrowheads point to the demyelinated regions. Scale bars for $A, B$ and $C=100 \mu \mathrm{M}$. D. High magnification (40x) of immunostained cerebellar lesion from JM 22019 showing numerous CD163+ macrophage/activated microglia (brown) immunoreactive for myelin basic protein (MBP, gray). Arrowheads point to a representative macrophage/activated microglia immunoreactive for MBP. E. High magnification (40x) image of immunostained internal capsule lesion from JM 30760 showing fewer CD163+ macrophage/activated microglia (brown) immunoreactive for MBP (gray). Arrowhead points to a macrophage/activated microglia immunoreactive for MBP. F. High magnification (40x) of immunostained periventricular surface of inflammatory cell aggregates with arrowhead showing accumulation of CD20+ B cells. Scale bars for D, E and F = 10uM. G and $\mathbf{H}$. Immunostains demonstrating activated complement $3 \mathrm{Cd}$ deposition on axons and neurons of demyelinating lesions from JM 22019 and JM 30760. Arrowheads points to activated complement 3Cd deposition on axons. I. Microglial nodule in normal appearing white matter surrounding hippocampus of JM 30773. Scale bars for $\mathrm{G}, \mathrm{H}$ and I = $10 \mathrm{uM}$.

Figure 3. IL-17 positive staining in the active cerebellar lesion of animal JM 26174 with JME. High magnification (40x) images of double immunofluorescence staining for IL-17 (A, D, and $\mathrm{G}$; green), $\mathrm{CD}^{+} \mathrm{T}$ cells $(\mathrm{B}$, red), olig2+ oligodendrocytes $(\mathrm{E}, \mathrm{red})$, and GFAP+ activated astrocytes $(H$, red) taken from the demyelinating cerebellar lesion in JM 26174. The overlay demonstrates IL-17 positive staining in CD3+ T cells (C, arrowheads), oligodendrocytes ( $F$, arrowheads), and in astrocytes (I, arrowheads). Scale bars $=10 \mu \mathrm{M}$.

Figure 4. Analysis of CNS mononuclear cell infiltrates in active CNS lesions of JME animals. A. Flow cytometry was used to analyze T cell populations infiltrating CNS lesions 
isolated from five JME animals (JMs 22019, 31509, 27624, 31852 and 31522). Mononuclear cells (MNCs) were stained with anti-CD4 and anti-CD8. Bars represent the percentage of lymphocytes expressing $\mathrm{CD}^{+}$(white) or $\mathrm{CD}^{+}$(grey). B. Infiltrating MNCs were stimulated for 6 hours with PMA and ionomycin in the presence of Brefeldin A followed by intracellular cytokine staining for IL-17 and IFN- $\gamma$. Plots show the percentage of IL-17 and IFN- $\gamma$ expressing cells within $\mathrm{CD}^{+}$or $\mathrm{CD}^{+} \mathrm{T}$ cell populations gated on $\mathrm{CD}^{+}$.

\section{Figure 5. Cerebrospinal fluid analysis of samples obtained from animals with JME and} age- and gender-matched healthy controls. A. ELISA results of IgG concentration (milligrams per deciliter) in the cerebrospinal fluid (CSF) of animals with JME compared to age- and gendermatched healthy control $(\mathrm{HC})$ animals. Each point represents CSF from an individual animal. The horizontal line indicates the mean and the error bars correspond to the standard error of the mean. IgG concentrations were significantly higher in the CSF of JME animals than in HC. Statistical significance was calculated using an unpaired t test. B. The CSF IgG index for each JME and HC animal is shown. The horizontal line indicates the mean CSF IgG index for each group and the error bars correspond to the standard error. An unpaired t test was utilized to determine that the difference between the two groups was statistically significant. C. Oligoclonal band (OCB) profiles of animals with JME. Matched CSF and diluted plasma from three representative animals with JME were resolved by isoelectric focusing (IEF), transferred to nitrocellulose and IgG detected by immunoblotting with a horseradish peroxidase conjugated mouse anti-human IgG (clone G18-145). The arrows indicate OCBs in the CSF for animals 31509 and 30773, which had 2 and 5 OCBs, respectively. No OCBs were detected in the CSF of animal 31852. Samples were run at least twice and representative blots are shown. 

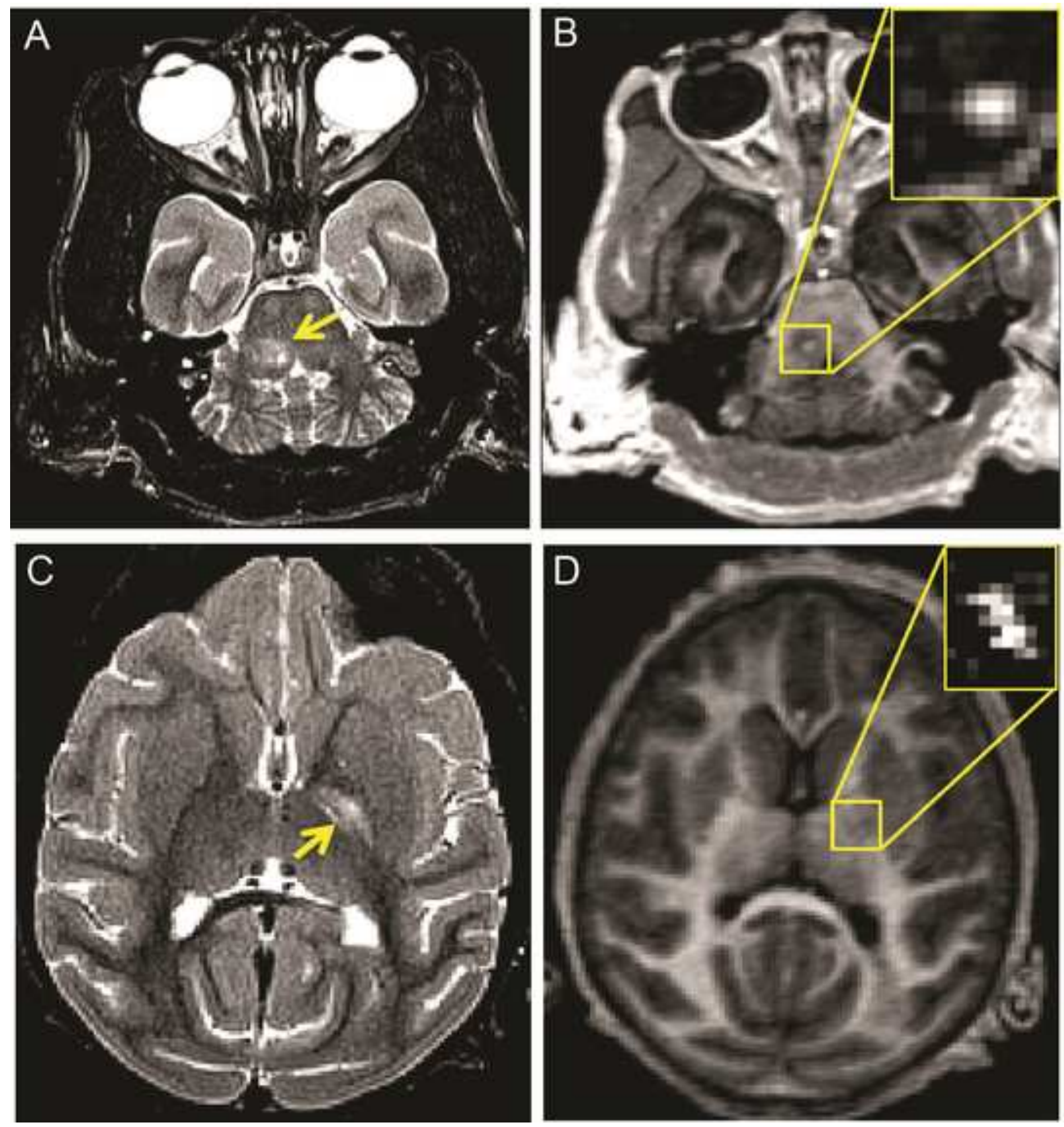

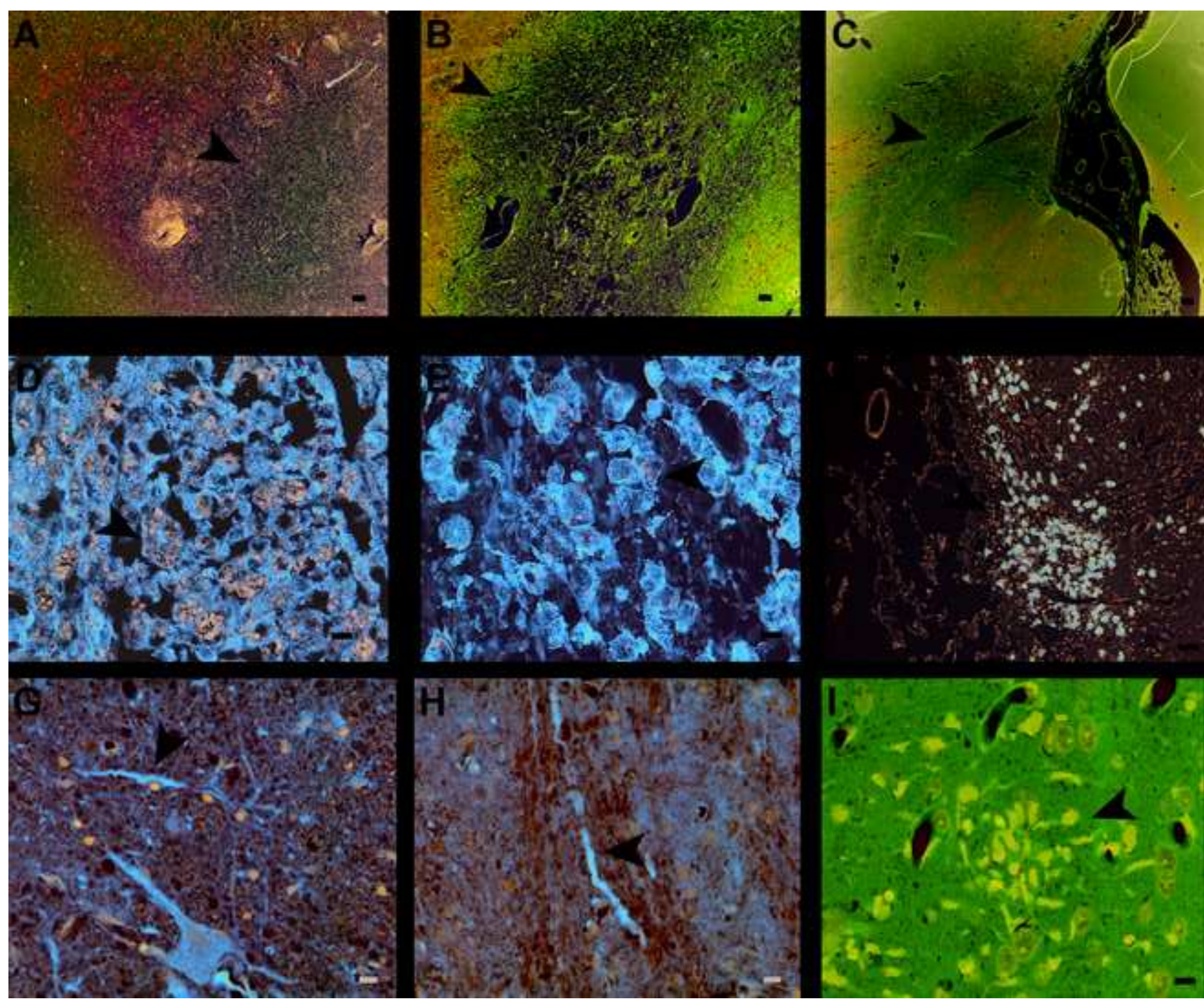

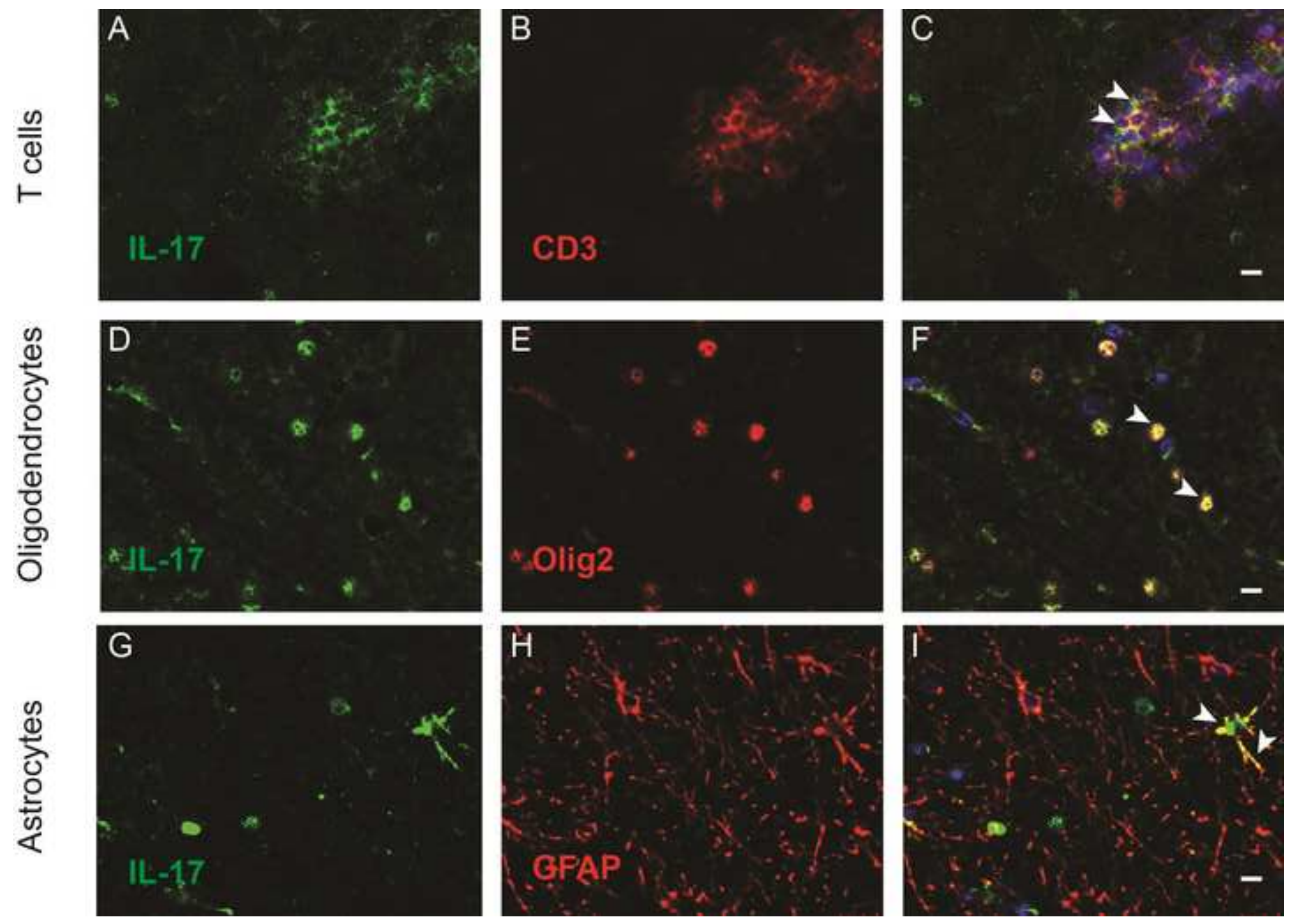
A
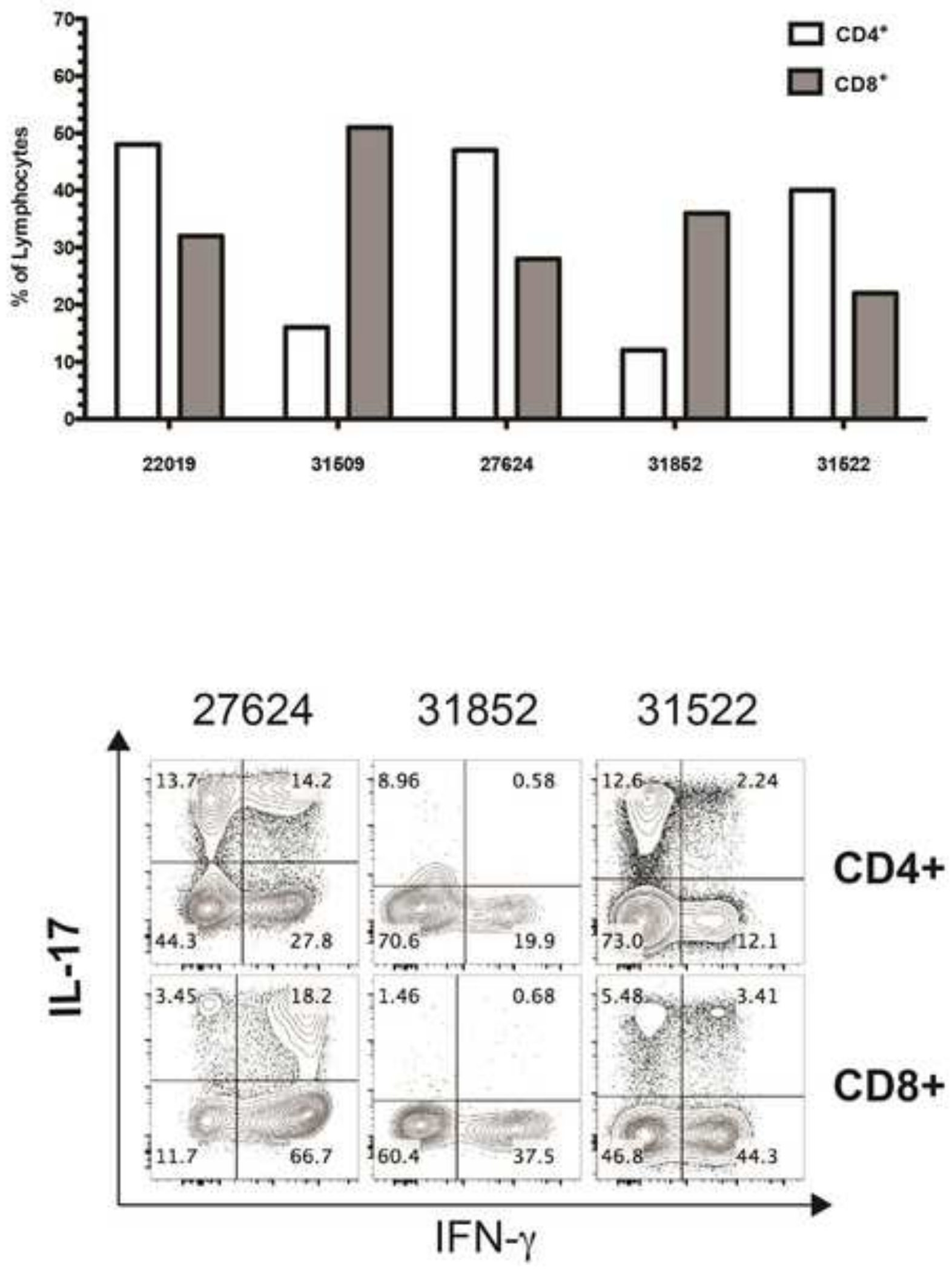

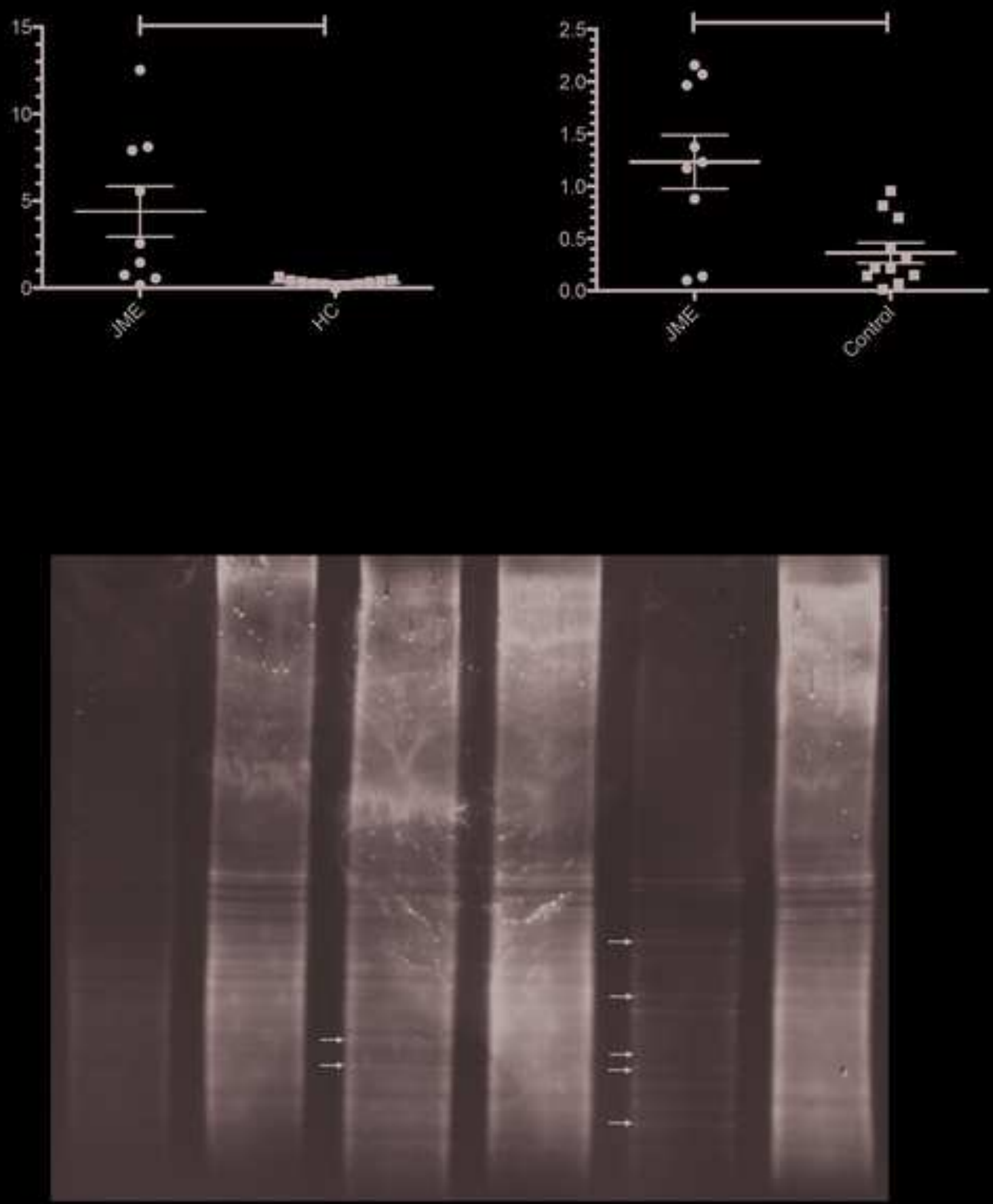

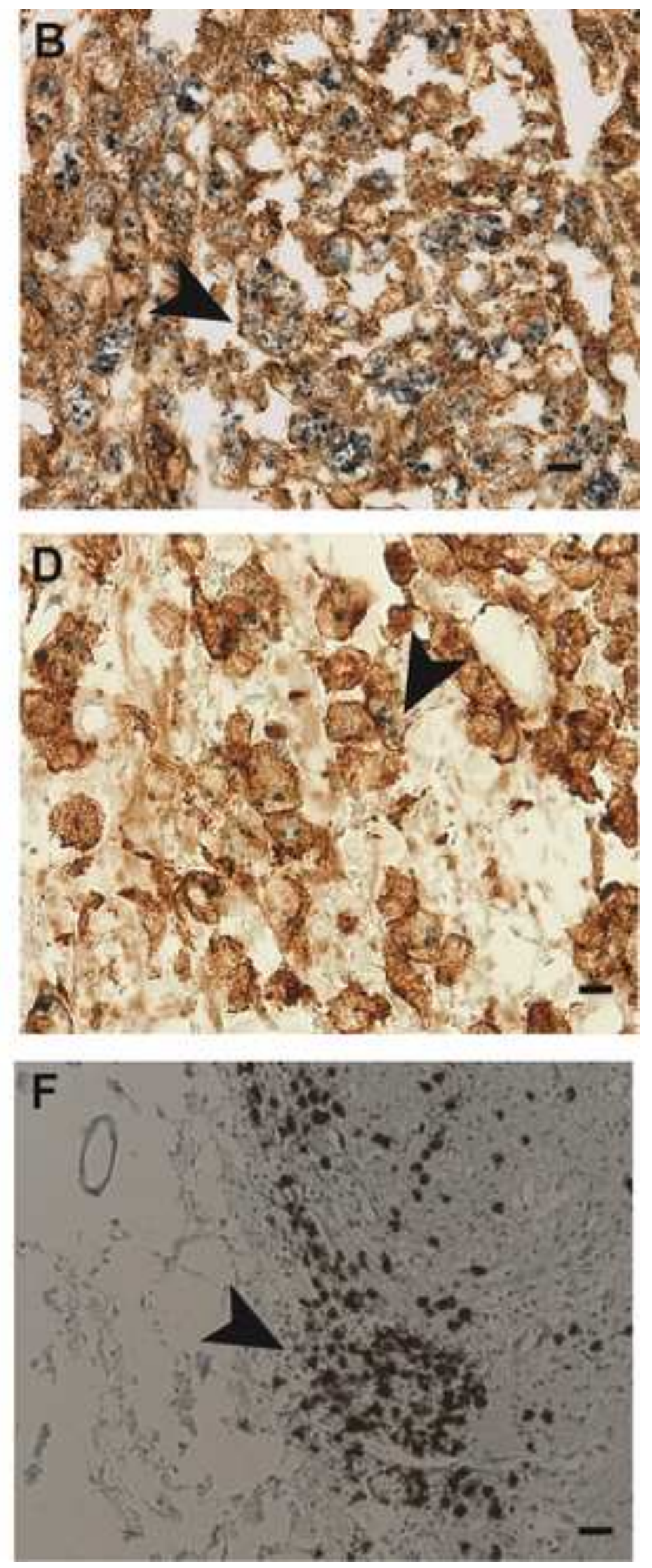
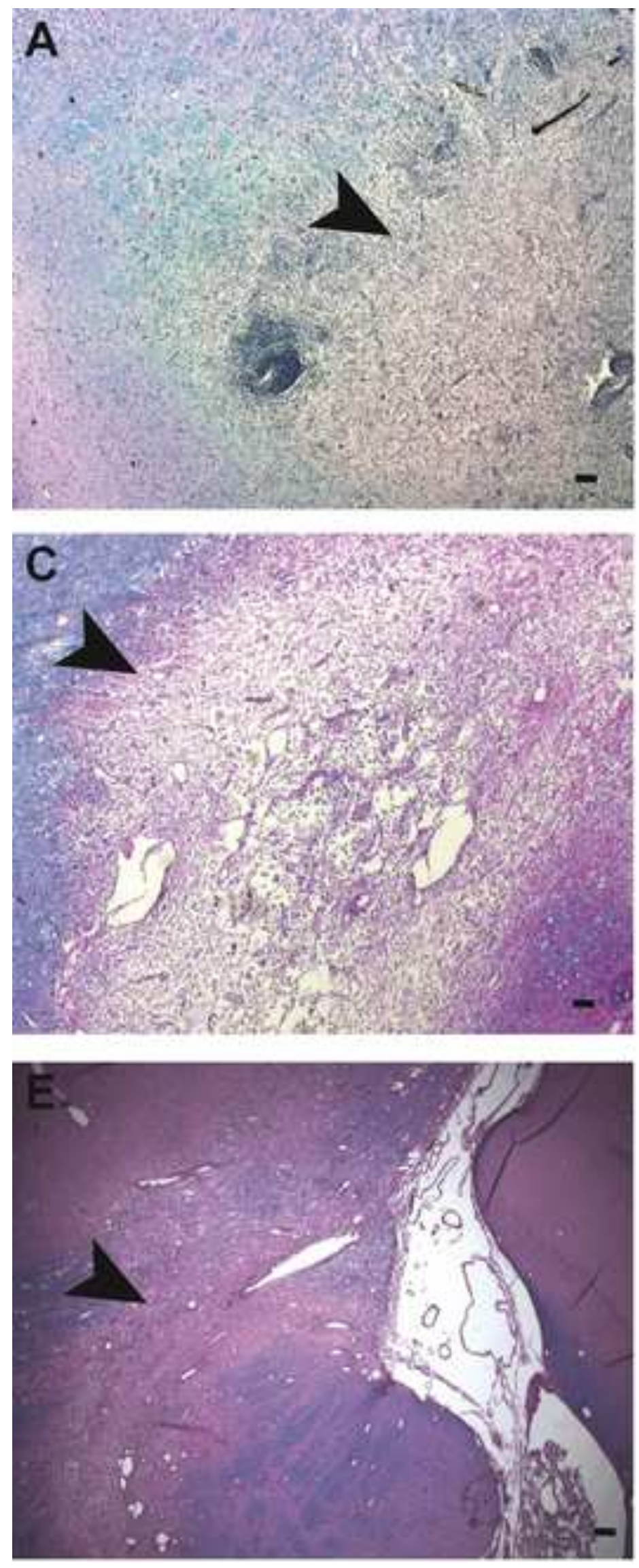

\section{.}

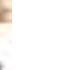

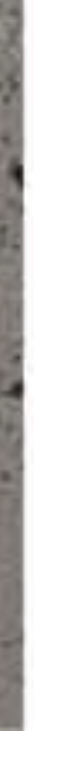


Table 1. Animal history and condition

\begin{tabular}{|c|c|c|c|c|c|}
\hline $\begin{array}{c}\text { Animal } \\
\text { ID }\end{array}$ & $\begin{array}{l}\text { JME }^{\mathrm{a}} / \text { gadolinium+ } \\
\text { MR lesions }\end{array}$ & $\begin{array}{c}\text { Age } \\
\text { (years/days) }\end{array}$ & Gender & $\begin{array}{l}\text { Histopathology } \\
\text { (CD163/MBP) }\end{array}$ & IL-17+ staining \\
\hline $13221^{b}$ & $\begin{array}{l}\text { JME/pons and } \\
\text { peduncule/cerebellum/ } \\
\text { spinal cord }\end{array}$ & $26 \mathrm{y} / 50 \mathrm{~d}$ & $\bar{F}$ & ${\mathrm{CD} 163^{+} / \mathrm{MBP}^{+}}^{+}$ & $\mathrm{CD}^{+} /$Olig2 $^{+}$ \\
\hline 19615 & $\begin{array}{l}\text { JME/cerebellum/brain } \\
\text { stem/Cerebral white } \\
\text { matter/spinal cord }\end{array}$ & $14 y / 103 d$ & M & $\mathrm{CD} 163^{+} / \mathrm{MBP}^{+}$ & CD3+/Olig2+ \\
\hline 22019 & $\begin{array}{l}\text { JME/cerebellum/brain } \\
\text { stem/ spinal cord }\end{array}$ & $13 y / 186 d$ & $\mathrm{~F}$ & $\mathrm{CD}_{163}{ }^{+} \mathrm{MBP}^{+}$ & $\mathrm{CD}^{+} / \mathrm{Olig}^{+}$ \\
\hline 27624 & $\begin{array}{l}\text { JME/corpus callosum } \\
\text { /cerebellum/internal } \\
\text { capsule }\end{array}$ & $6 y / 12 d$ & $\mathrm{~F}$ & CD163+/MBP- & $\mathrm{CD}^{+}$ \\
\hline 31522 & $\begin{array}{l}\mathrm{JME} / \text { pons and } \\
\text { peduncule/cerebellum/ } \\
\text { cerebral white matter }\end{array}$ & $2 y / 293 d$ & $\mathrm{~F}$ & $\mathrm{CD}_{163}{ }^{+} \mathrm{MBP}^{+}$ & Olig2+ \\
\hline $26174^{b}$ & $\begin{array}{l}\text { JME/cerebellum/brain } \\
\text { stem/spinal cord }\end{array}$ & $2 y / 229 d$ & M & $\mathrm{CD}_{163^{+}} / \mathrm{MBP}^{+}$ & $\begin{array}{l}\mathrm{CD3}^{+} / \mathrm{Olig2}^{+} / \\
\mathrm{GFAP}^{+}\end{array}$ \\
\hline 31852 & $\begin{array}{l}\text { JME/midbrain to } \\
\text { subcortical/spinal cord }\end{array}$ & $1 \mathrm{y} / 287 \mathrm{~d}$ & $\mathrm{~F}$ & $\mathrm{CD} 163^{+} / \mathrm{MBP}^{+}$ & Olig2 $^{+}$ \\
\hline 30493 & JME/internal capsule & $1 \mathrm{y} / 282 \mathrm{~d}$ & M & $\mathrm{CD} 163^{+} / \mathrm{MBP}^{+}$ & Not detected \\
\hline 30773 & $\begin{array}{l}\mathrm{JME} / \text { cerebellum/ } \\
\text { cerebral white matter }\end{array}$ & $1 \mathrm{y} / 074 \mathrm{~d}$ & M & $\mathrm{CD} 163^{+} / \mathrm{MBP}^{+}$ & $\begin{array}{l}\text { CD3+/Olig2+/ } \\
\text { GFAP+ }\end{array}$ \\
\hline 31509 & $\begin{array}{l}\text { JME/bilateral } \\
\text { cerebellum }\end{array}$ & $1 y / 126 d$ & M & $\mathrm{CD} 163^{+} / \mathrm{MBP}^{-}$ & $\mathrm{CD}^{+}$ \\
\hline 30760 & JME/internal capsule & $1 \mathrm{y} / 105 \mathrm{~d}$ & $\mathrm{~F}$ & $\mathrm{CD} 163^{+} / \mathrm{MBP}^{+}$ & $\begin{array}{l}\mathrm{CD3}^{+} / \mathrm{Olig2}^{+} / \\
\mathrm{GFAP}^{+} \\
\end{array}$ \\
\hline
\end{tabular}

aJME was reported previously (Axthelm et al., 2011). Clinical signs included ataxia, paralysis or paresis of one or more limbs, and ocular abnormalities.

'MRI from these animals' CNS were previously reported (Axthelm et al., 2011). 
Table 2. CSF and plasma analysis of JME and HC animals

\begin{tabular}{|c|c|c|c|c|c|c|}
\hline $\begin{array}{c}\text { Animal } \\
\text { ID }\end{array}$ & $\begin{array}{l}\text { CSF IgG } \\
(\mathrm{mg} / \mathrm{dL})\end{array}$ & $\begin{array}{c}\text { Plasma } \\
\text { lgG } \\
(\mathrm{mg} / \mathrm{dL})\end{array}$ & $\begin{array}{c}\text { CSF } \\
\text { albumin } \\
\text { (mg/dL) }\end{array}$ & $\begin{array}{l}\text { Plasma } \\
\text { albumin } \\
\text { (mg/dL) }\end{array}$ & $\begin{array}{l}\text { CSF IgG } \\
\text { Index }\end{array}$ & $\begin{array}{l}\text { Oligoclonal } \\
\text { bands }\end{array}$ \\
\hline $18276^{\mathrm{a}}$ & 0.17 & 103.68 & 28 & 2364 & 0.138 & $\bar{Y}$ \\
\hline $19615^{\mathrm{a}}$ & 5.55 & 372.16 & 60 & 4705 & 1.169 & $\mathrm{~N}$ \\
\hline $22019^{a}$ & 1.45 & 186.12 & 38 & 4285 & 0.879 & $Y$ \\
\hline $27624^{a}$ & 7.90 & 511.92 & 58 & 4625 & 1.231 & $Y$ \\
\hline $31852^{a}$ & 0.74 & 47.16 & 39 & 4885 & 1.965 & $N$ \\
\hline $30493^{a}$ & 0.56 & 283.23 & 80 & 4055 & 0.100 & $Y$ \\
\hline $30773^{a}$ & 2.56 & 311.85 & 29 & 4860 & 1.376 & $Y$ \\
\hline $31509^{a}$ & 8.11 & 172.92 & 81 & 3725 & 2.157 & $Y$ \\
\hline \multirow[t]{2}{*}{$30760^{a}$} & 12.53 & 299.57 & 101 & 4995 & 2.069 & $Y$ \\
\hline & $4.397 \pm 1.45$ & $254.3 \pm 47.6$ & $57.1 \pm 8.63$ & $4278 \pm 277.5$ & $1.23 \pm 0.26$ & \\
\hline $19616^{b}$ & 0.39 & 152.85 & 30 & 4770 & 0.406 & $\mathrm{~N}$ \\
\hline $19895^{b}$ & 0.46 & 80.63 & 31 & 4425 & 0.814 & $N$ \\
\hline $20471^{b}$ & 0.25 & 81.12 & 25 & 5675 & 0.700 & $\mathrm{~N}$ \\
\hline $24636^{b}$ & 0.64 & 239.88 & 53 & 6040 & 0.304 & $\mathrm{~N}$ \\
\hline $25473^{b}$ & 0.43 & 421.68 & 25 & 3685 & 0.150 & $N$ \\
\hline $25457^{b}$ & 0.22 & 40.68 & 29 & 5120 & 0.955 & $N$ \\
\hline $29202^{b}$ & 0.32 & 280.02 & 25 & 4690 & 0.214 & $N$ \\
\hline $29734^{b}$ & 0.22 & 382.00 & 25 & 6210 & 0.143 & $\mathrm{~N}$ \\
\hline $29759^{b}$ & 0.14 & 391.70 & 25 & 4865 & 0.070 & $N$ \\
\hline $30761^{b}$ & 0.03 & 284.52 & 31 & 4045 & 0.014 & $N$ \\
\hline \multirow[t]{3}{*}{$30765^{b}$} & 0.34 & 214.37 & 34 & 4710 & 0.220 & $N$ \\
\hline & $0.31 \pm 0.05$ & $233.6 \pm 40.2$ & $30.27 \pm 2.47$ & $4930 \pm 237.1$ & $0.36 \pm 0.10$ & \\
\hline & $p<0.006$ & $p<0.74$ & $p<0.004$ & & $p<0.003$ & \\
\hline
\end{tabular}

${ }^{\mathrm{a} A n i m a l s}$ with JME

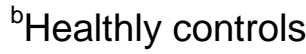


27624

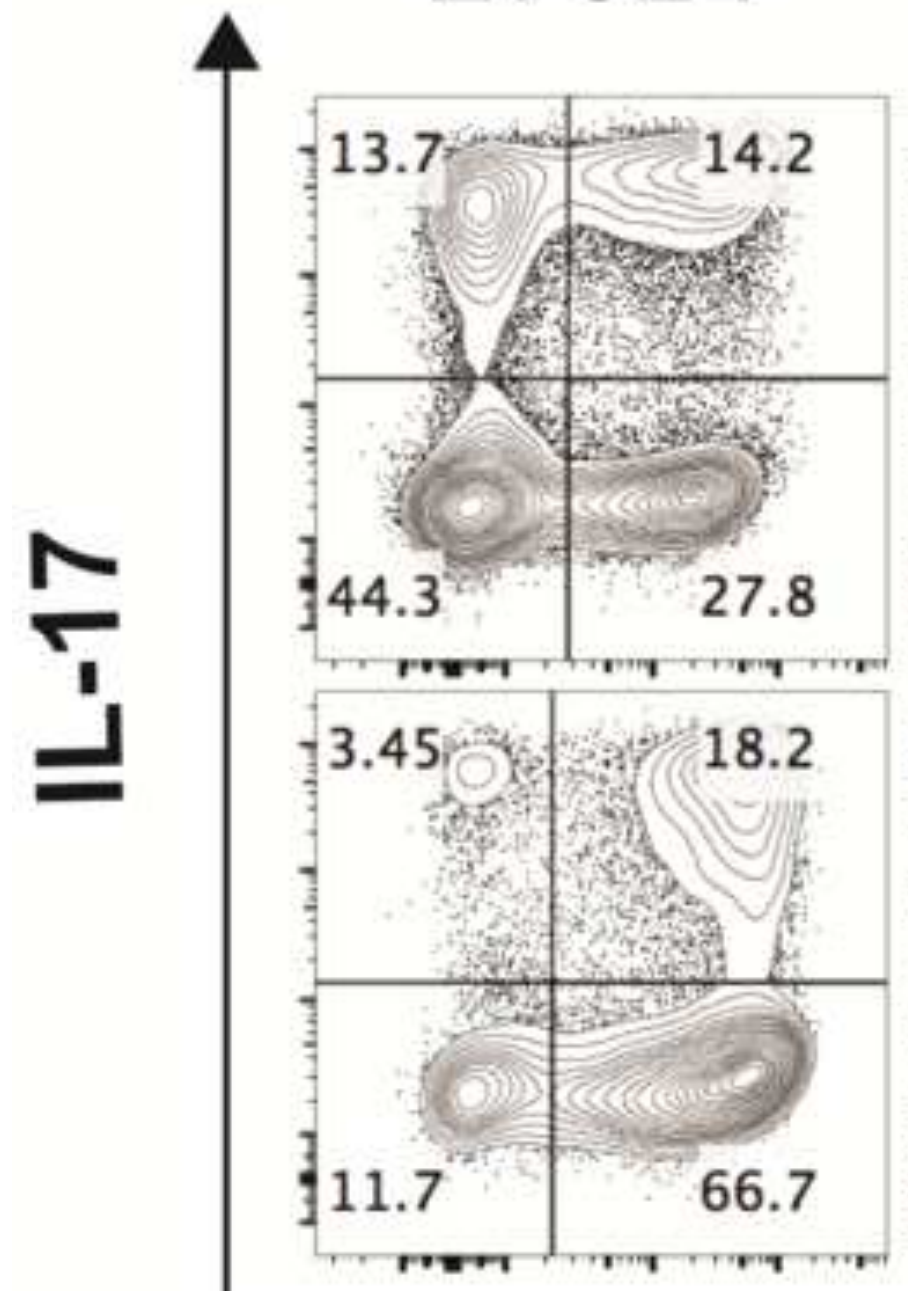

31852

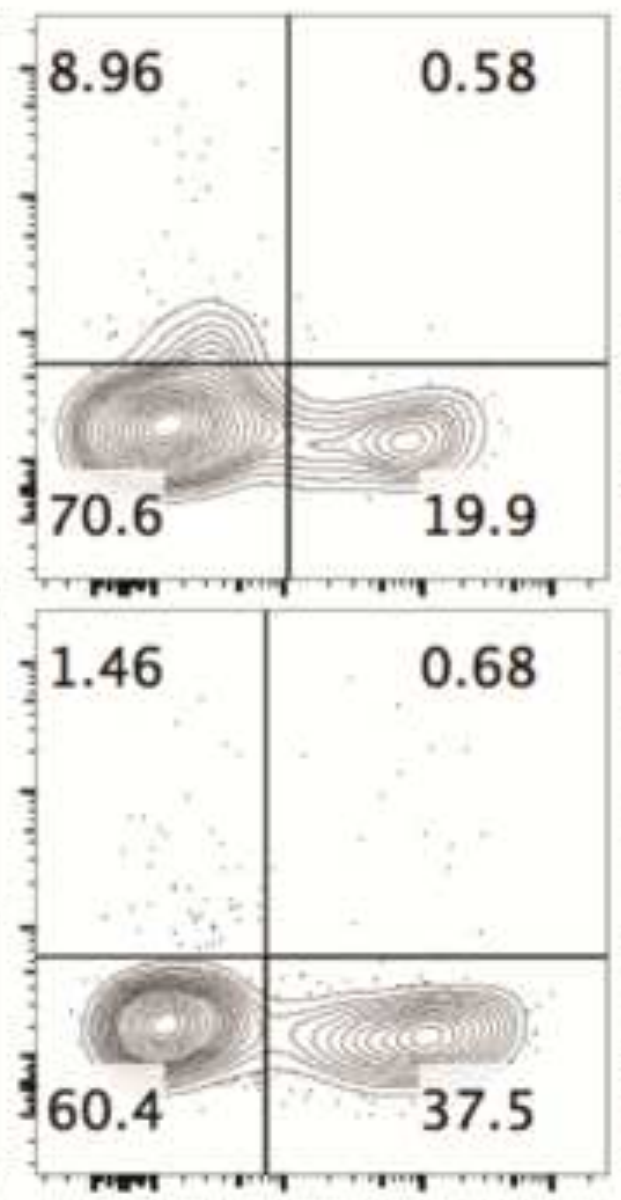

31522

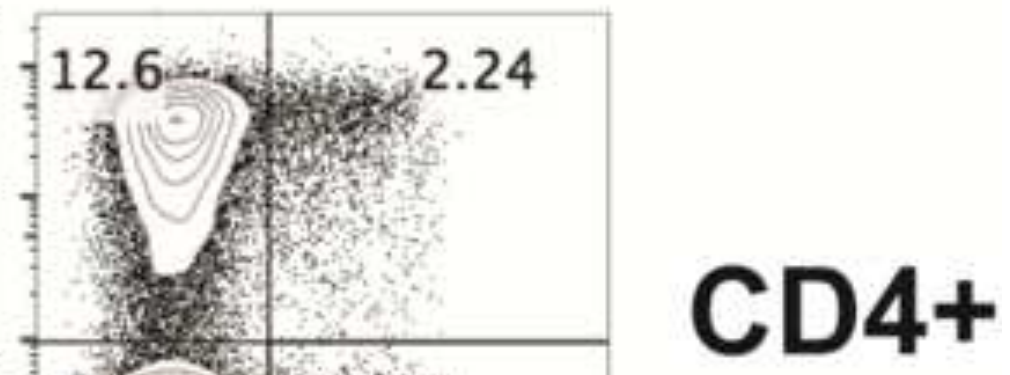

IFN- $\gamma$

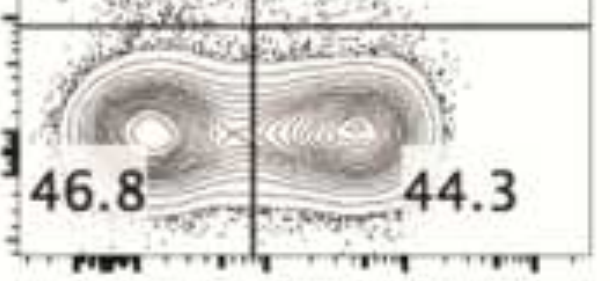

CD8+ 